\title{
Seasonal fluctuations of cosmopolitan inversion frequencies in a natural population of Drosophila melanogaster
}

\author{
F Sanchez-Refusta*, E Santiago, J Rubio \\ Universidad de Oviedo, Departamento de Biologia Funcional (Genética), \\ 33071 Oviedo, Spain
}

(Received 10 June 1988; accepted 30 October 1989)

Summary - Seasonal changes in the frequencies of cosmopolitan inversions and In(3R)C have been investigated in a Spanish population of Drosophila melanogaster for 4 years. Regression and Fourier analysis methods were used to separate the temporal variation of the frequencies into linear and cyclic components. Different patterns in temporal variation were detected. The frequency of $\operatorname{In}(2 \mathrm{R}) \mathrm{NS}$ was stable; In(3R)C tended to increase its frequency across the years; $\operatorname{In}(3 \mathrm{R}) \mathrm{P}$ showed oscillations that could not be attributed to cyclic changes. In $(2 \mathrm{~L}) \mathrm{t}$ and $\operatorname{In}(3 \mathrm{~L}) \mathrm{P}$ showed seasonal cyclic changes with increasing frequencies during the warm months, which are thought to be mainly due to the superior relative fitness of heterozygotes, as compared with inversion non-carrier individuals. The fall of frequencies in the cold months is probably a consequence of the shorter lifespan of the carriers of these inversions during the winter. The differences between the temporal variation patterns of the inversions do not support the hypothesis of a single climatic factor as being responsible for the geographic cline of the cosmopolitan inversions. Without ignoring the influence of underlying selective factors of macroclimatic nature, other ecological and genetical factors uncorrelated with latitude are suggested to play a role in the temporal dynamics of the inversions, as well as in their geographic distribution.

Drosophila melanogaster / inversion frequency / seasonal change

Résumé - Fluctuations saisonnières des fréquences d'inversions cosmopolites dans une population naturelle de Drosophila melanogaster - Les variations saisonnières des fréquences de plusieurs inversions cosmopolites et de $\operatorname{In}(3 R) C$ ont été étudiées dans une population espagnole de Drosophila melanogaster pendant 4 ans. Des méthodes de régression et d'analyse de Fourier ont été utilisées pour séparer les variations temporelles en composantes linéaires et en composantes cycliques. On a détecté différents profils de variation temporelle. La fréquence de l'inversion $\operatorname{In}(2 R) N S$ est restée stable, celle de $\operatorname{In}(3 R) C$ a eu tendance à crốtre au cours des années, celle de In(3R) $P$ a montré des oscillations non périodiques. Les fréquences de In(2L)t et de In(3L)P ont montré des variations saisonnières cycliques, avec un accroissements des fréquences pendant les mois chauds, qu'on peut rattacher à une fitness relative supérieure des hétérozygotzes par rapport aux individus non porteurs d'une inversion; la baisse des fréquences pendant les mois froids est probablement une conséquences de la durée de vie plus brève des porteurs de ces

* Correspondence and reprints 
inversions pendant les mois d'hiver. Les différences de profils des variations saisonnières de ces inversions ne sont pas en accord avec l'hypothèse selon laquelle un seul facteur climatique serait responsable du gradient géographique des fréquences des inversions cosmopolites. Sans exclure l'influence de facteurs sélectifs d'origine microclimatique, on suggère que d'autres facteurs écologiques et génétiques, non corrélés avec la latitude, joueraient un rôle dans la dynamique temporelle des fréquences des inversions ainsi que dans leur répartition géographique.

Drosophila melanogaster / fréquence d'inversion / variation saisonnière

\section{INTRODUCTION}

Natural populations of Drosophila melanogaster are polymorphic for chromosome inversions; especially for the 4 inversions termed "common cosmopolitan" by Mettler et al (1977). These are: $\operatorname{In}(2 \mathrm{~L}) \mathrm{t}, \operatorname{In}(2 \mathrm{R}) \mathrm{NS}, \operatorname{In}(3 \mathrm{~L}) \mathrm{P}$ and $\operatorname{In}(3 \mathrm{R}) \mathrm{P}$. Strong latitudinal clines in the frequencies of the 4 inversions have been described in the USA (Mettler et al, 1977; Stalker, 1980), Japan (Inoue and Watanabe, 1979; Inoue et al, 1984) and Australia (Knibb et al, 1981; Anderson et al, 1987). The frequency of each inversion diminishes the further it is from the equator. This seems to be a general feature, despite the results found in Japanese populations by Inoue $e t$ al (1984), where the lack of correlation between latitude and frequency of cosmopolitan inversions could be due to the small scale of sampling (Anderson et al, 1987).

The parallel chromosomal changes with latitude suggest an adaptation to ecological differences associated with climate (explanations involving only random processes can be discounted by the similar directions in the two hemispheres). Ecological differences are obviously diverse and complex. In a revision work, Knibb (1982) studied the correlation among the frequency of inversions and some macroclimatic variables. He found that the frequencies were generally positively correlated with temperature. Stalker (1980) found temperature-dependent differences between karyotypes in flying ability. But no causal effect of temperature on inversion frequencies may be asserted. At present, the cause of the latitudinal cline is an open problem.

If the reason were simply the adaptation of inversion carrier individuals to higher temperature, some periodic seasonal fluctuations of the inversion frequency should be detected. In fact, Stalker (1980) found a significant shift from May to October of the inversions on the right arms of chromosomes II and III. Knibb (1986) reported seasonal variations repeated over 2 years for $\operatorname{In}(2 \mathrm{R}) \mathrm{NS}$ and $\operatorname{In}(3 \mathrm{~L}) \mathrm{P}$. Two other works deal with seasonal fluctuations (Zacharopoulou and Pelecanos, 1980; Inoue et al, 1984), but no significant periodical changes were detected.

In this paper, we describe a temporal evolution of the chromosomal polymorphism in a Northern Spanish population in Drosophila melanogaster for 4 years. We present evidence that periodical seasonal changes play an important role in the dynamic of inversion frequencies of this population, but there are clear differences between temporal data and that expected from 1 single selective climatic factor acting on the inversions. 


\section{MATERIALS AND METHODS}

Wild flies were captured in a nearby wood (Los Areneros; $7 \mathrm{~km}$ from Oviedo; $43.2^{\circ}$ latitude, $5.9^{\circ}$ longitude). Twenty-one samples were collected around the 15 th day of each month from June to November in the years 1981-1984 (samples were taken in July 1981, August 1982 and August 1984). Banana and live-yeast traps were left in the wild for 3 days; flies were collected in the afternoon.

Females inseminated in nature were kept individually in vials, and salivary gland chromosomes from a single larva of the progeny of each vial were examined. Chromosomes were prepared as described by Levine and Schwartz (1970).

Because of data type and the different sample sizes, the temporal trend analyses were performed by using the least $\chi^{2}$ method. First, temporal inversion frequencies were analysed to detect linear trends. The monthly frequencies were adjusted to a linear regression on the ordinal number of each month (from 1 to 48 across the 4 years, although a few months are missing). The $\chi_{1 d f}^{2}$ value to test the linear trend hypothesis was calculated as the difference between the heterogeneity among samples $\chi_{20 d f}^{2}$ and the adjusted linear regression deviation $\chi_{19 d f}^{2}$.

Secondly, statistical analysis, in order to detect a year-by-year cyclic variation pattern, was performed. Fourier series equations with only 1 harmonic, frequently used in analysis of sequential data (Yule and Kendall, 1950), were applied. As linear trends were detected, the Fourier equations were corrected for the linear trend. The general periodic equation which expresses the expected inversion frequencies $\left(Y_{i}\right)$ for every month $\left(x_{i}\right)$ can be written as:

$$
Y_{i}=\mu+\sigma x_{i}+\alpha C+\beta S
$$

with $C=\cos \left(2 \pi x_{i}\right) / \theta ; S=\sin \left(2 \pi x_{i}\right) / \theta$

where $\theta$ is the period in months; $\mu, \sigma$ (regression coefficient), and $\alpha$ and $\beta$ are the coefficients of the modified periodic equation. The $x$ variable can take any value between 1 and 48. If inversion frequencies were really fluctuating according to a yearly cyclic pattern, the adjustment to the periodic equation would be better for a period of around 12 months. If this is not so, the previous adjustment is thought not to be significant and does not improve other $\theta$ values. Consequently, for each inversion frequency series, 11 equations were performed corresponding to the 11 values of $\theta$ ranging between 7 and 17 months. The $\chi_{2 d f}^{2}$ value to test the cyclic pattern hypothesis for each $\theta$ value, is estimated as the difference between the linear regression deviation $\chi_{19 d f}^{2}$ previously calculated, and the corresponding periodic equation deviation $\chi_{17 d f}^{2}$ ( $\mu, \sigma, \alpha$ and $\beta$ are estimated in this adjustment). To allow comparisons among different period adjustment equations, the $11 \chi_{2 d f}^{2}$ values for each inversion are plotted against the corresponding $\theta$ values on a "periodicity testing" chart. All the least $\chi^{2}$ adjustments were made by using computer-aided approximations.

Average monthly temperature and rainfall were used to check the correlation of macroclimatic data with the inversion frequencies. The correlation coefficients of Spearman $\left(r s_{19 d f}\right)$ were calculated between the serial frequencies of each inversion and the 2 macroclimatic variables for the trapping month, as well as for the previous 7 months. Climatic data were obtained from the Observatorio Meteorológico de Oviedo, $7 \mathrm{~km}$ away from the collecting site. 


\section{RESULTS}

The most abundant Drosophila genus species found during the trapping period were $D$ melanogaster, $D$ immigrans and $D$ simulans. $D$ melanogaster was dominant in June and July, but $D$ simulans increased rapidly, becoming most abundant during August and September. The number of individuals caught in November decreased drastically, becoming null from December to May.

Many inversions were found, some of them described for the first time (Roca et al, 1982). However, in this work we shall deal only with those that were sampled at a frequency over $5 \%$. These were the 4 common cosmopolitan inversions and the In(3R)C, labelled as "rare cosmopolitan" by Mettler et al (1977). The frequencies of these polymorphic inversions in the various samples during the years 1981-1984 are given in Table I. Only In(2R)NS did not present significant changes in frequency; nevertheless, linear trend $\chi_{1 d f}^{2}$ was significant, although very close to the 0.05 limit. The 2 inversions on the right arm of chromosome III showed an increasing frequency trend with time. This trend was highly significant for $\operatorname{In}(3 \mathrm{R}) \mathrm{C}$, which increased at a rate of $2.2 \%$ each year. In fact, the linear regression explains most of the temporal frequency changes of this inversion: the remaining $\chi_{19 d f}^{2}$, after the linear regression adjustment, was significant only at the 0.05 level. Fig 1 graphically shows the temporal oscillations of the 5 inversion frequencies.

Table I. Frequencies (\%) of inversions per major autosome arm and partition of the $\chi^{2}$ of heterogeneity among samples.

\begin{tabular}{|c|c|c|c|c|c|c|}
\hline Month & $\begin{array}{l}\text { No of autosome } \\
\text { sets tested }\end{array}$ & $\operatorname{In}(2 L) t$ & $\operatorname{In}(2 R) N S$ & $\operatorname{In}(3 L) P$ & $\operatorname{In}(3 R) P$ & $\operatorname{In}(3 R) C$ \\
\hline $\begin{array}{ll}\text { Jun } 81 \\
\text { Aug } 81 \\
\text { Sep } 81 \\
\text { Oct } 81 \\
\text { Nov } 81 \\
\text { Jun } 82 \\
\text { Jul } 82 \\
\text { Sep } 82 \\
\text { Oct } 82 \\
\text { Nov } 82 \\
\text { Jun } 83 \\
\text { Jul } 83 \\
\text { Aug } 83 \\
\text { Sep } 83 \\
\text { Oct } 83 \\
\text { Nov } 83 \\
\text { Jun } 84 \\
\text { Jul } 84 \\
\text { Sep } 84 \\
\text { Oct } 84 \\
\text { Nov } 84\end{array}$ & $\begin{array}{r}180 \\
170 \\
134 \\
130 \\
34 \\
312 \\
74 \\
102 \\
84 \\
74 \\
90 \\
102 \\
226 \\
98 \\
124 \\
60 \\
112 \\
170 \\
128 \\
134 \\
56\end{array}$ & $\begin{array}{l}15.0 \\
21.1 \\
26.8 \\
22.3 \\
32.3 \\
20.5 \\
18.9 \\
33.3 \\
27.3 \\
32.4 \\
20.0 \\
11.7 \\
22.1 \\
27.5 \\
18.5 \\
18.3 \\
18.7 \\
24.1 \\
29.6 \\
31.3 \\
28.5\end{array}$ & $\begin{array}{r}14.4 \\
12.9 \\
17.1 \\
10.7 \\
8.8 \\
11.8 \\
10.8 \\
17.6 \\
16.6 \\
13.5 \\
15.5 \\
15.6 \\
14.6 \\
10.2 \\
10.4 \\
13.3 \\
8.0 \\
8.2 \\
10.9 \\
9.7 \\
10.7 \\
\end{array}$ & $\begin{array}{r}7.2 \\
21.1 \\
22.3 \\
25.3 \\
8.8 \\
14.4 \\
21.6 \\
37.2 \\
29.7 \\
24.3 \\
13.3 \\
23.5 \\
14.1 \\
11.2 \\
14.5 \\
15.0 \\
14.2 \\
16.4 \\
18.7 \\
22.3 \\
14.2 \\
\end{array}$ & $\begin{array}{r}3.3 \\
15.8 \\
14.1 \\
13.5 \\
23.5 \\
18.5 \\
14.8 \\
30.3 \\
19.0 \\
12.1 \\
12.2 \\
18.6 \\
17.2 \\
19.3 \\
17.7 \\
26.6 \\
13.3 \\
17.0 \\
22.6 \\
17.9 \\
16.0 \\
\end{array}$ & $\begin{array}{r}10.0 \\
8.2 \\
11.1 \\
12.3 \\
5.8 \\
14.7 \\
12.1 \\
20.5 \\
5.9 \\
16.2 \\
13.3 \\
23.5 \\
19.9 \\
14.2 \\
10.4 \\
11.6 \\
9.8 \\
20.5 \\
17.1 \\
16.4 \\
14.2 \\
\end{array}$ \\
\hline \multirow{2}{*}{\multicolumn{2}{|c|}{$\begin{array}{l}\chi_{20 d f}^{2} \text { heterogeneity: } \\
-\chi_{1 d f}^{2} \text { linear trend: } \\
\text { (freq. increasing/year) } \\
-\chi_{19 d f}^{2} \text { deviations: }\end{array}$}} & $43.7^{* *}$ & $17.9 \mathrm{~ns}$ & $74.7^{* * *}$ & $52.0 * * *$ & $41.6^{* *}$ \\
\hline & & $\begin{array}{c}2.9 \mathrm{~ns} \\
1.2 \\
40.8^{* *}\end{array}$ & $\begin{array}{c}4.1^{*} \\
-1.3 \\
13.8 \mathrm{~ns}\end{array}$ & $\begin{array}{l}1.2 \mathrm{~ns} \\
-0.8 \\
73.5^{* * *}\end{array}$ & $\begin{array}{c}4.8^{*} \\
1.6 \\
47.2^{* * *}\end{array}$ & $\begin{array}{c}10.8^{* * * *} \\
2.2 \\
30.8^{*}\end{array}$ \\
\hline
\end{tabular}




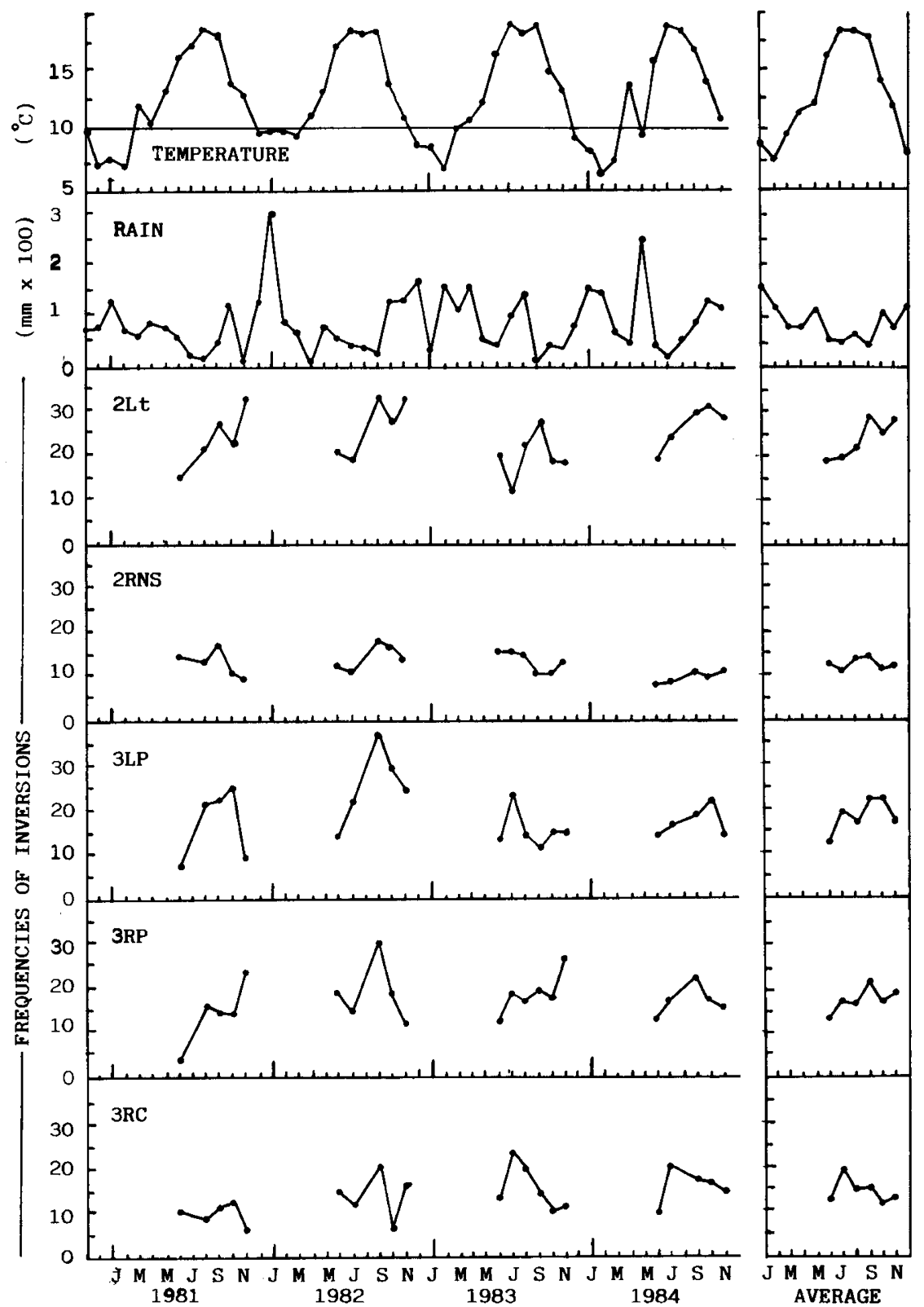

Fig 1. Four-year data of the average monthly temperature and rainfall, and frequency of the inversions. 
The "periodicity testing" charts (Fig 2) clearly underline the differences among the inversions. As expected, periodic fluctuations were not detected either for In(2R)NS (where sampling frequencies were homogeneous), or for $\operatorname{In}(3 \mathrm{R}) \mathrm{C}$ (where the linear trend explains most of the differences among samples). In(2L)t showed a maximal significant adjustment for the 12 -month period. The remaining deviations after the adjustment to the 12-month periodic equation were not significant $\left(\chi_{17 d f}^{2}=\right.$ 23.5). This implies that the fluctuating pattern of this inversion is mainly periodic; being repeated every year. $\mathrm{In}(3 \mathrm{~L}) \mathrm{P}$ also showed a maximal adjustment to a 12 month period. However, two observations should be noted: first, there was 1 peak for the 9-month period length, and second, all the adjustments to different period equations were significant. The wide wandering fluctuations of $\operatorname{In}(3 \mathrm{~L}) \mathrm{P}$ frequencies, together with the lack of samples for some months, allowed a great variety of periodic series to fit the data. In any case, the finding of a figure shape, with a maximum for a nearby 12-month period, indicates the existence of a year-to-year periodic pattern. The remaining $\operatorname{In}(3 \mathrm{~L}) \mathrm{P}$ deviations, after adjustment to the 12 month period function, were highly significant $\left(\chi_{17 d f}^{2}=40.9 ; P<0.001\right)$. Finally, the analysis of $\operatorname{In}(3 \mathrm{R}) \mathrm{P}$ evolution sheds no light on the existence of the cyclic component: the $\chi_{2 d f}^{2}$ value for a 12 -month period is not the maximum, being only significant at a level very close to 0.05 .
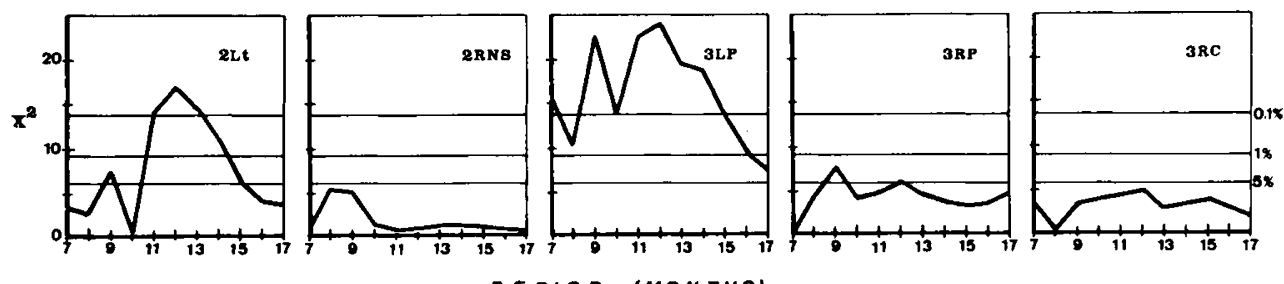

Fig 2. Periodicity testing charts for the 5 inversions. Horizontal lines mark the critical $\chi^{2}$ values for 3 significance levels.

The cyclic pattern of $\operatorname{In}(2 \mathrm{~L}) \mathrm{t}$ and $\operatorname{In}(3 \mathrm{~L}) \mathrm{P}$ frequency fluctuations is strong evidence that a selective process is taking place (Lewontin, 1974), and that the relative fitness must be changing over the year. It is possible to estimate the confidence limits within which the relative fitness in a given season would lie when changes occur rapidly and repeatedly, as done by Dobzhansky (1943) for $D$ pseudoobscura third chromosome inversions. Both inversions increased their frequency during the period ranging from June to September, when the mean temperature was around $18^{\circ} \mathrm{C}$. At this temperature, the development time is close to 16 days (David and Clavel, 1967). According to the egg laying curves computed by McMillan et al (1970) (laboratory conditions at $25^{\circ} \mathrm{C}$ ), the mean egg laying could be around $9 \mathrm{~d}$. So, the mean generation time could be near $25 \mathrm{~d}$. Obviously, the effect of microclimate deviations and other ecological factors cannot be evaluated. It is reasonable to assume that the generation time would lie between 20 and $30 \mathrm{~d}$. Because of the low frequency of these 2 inversions over the 4 months (In(2L)t had a mean frequency of $22 \%$ and $\operatorname{In}(3 \mathrm{~L}) \mathrm{P}$ of $18 \%$ ), there is likely to be a low frequency of inversion homozygotes, so that the biological fitness of the inversion homozygote must have little influence on the frequency dynamics. So, the increasing frequency 
of each inversion should mainly be a result of greater heterozygote fitness in relation to the homozygous standard arrangement. As the $\mathrm{In}(2 \mathrm{~L}) \mathrm{t}$ frequency increase was $3.37 \%$ per month, the relative fitness of the heterozygote should lie between 1.18 and 1.28 (for 20 and $30 \mathrm{~d}$ of generation time, respectively). In(3L)P showed a frequency mean increase of $2.71 \%$ per month, so the relative heterozygote fitness should be between 1.16 and 1.25 .

Knibb (1986) found a positive and significant correlation of inversions $\operatorname{In}(2 \mathrm{~L}) \mathrm{t}$, In(2R)NS and In(3L)P with the temperature and rainfall of the previous month. Our data reveal that the $\operatorname{In}(2 \mathrm{~L}) \mathrm{t}$ frequency was positively and significantly correlated with the mean temperatures in the 2nd to 5 th months previous to the trapping; the correlation was maximized with the temperature of the 3rd previous month $(r s=0.54, P<0.01)$. The frequency of $\operatorname{In}(2 \mathrm{~L}) \mathrm{t}$ was also negatively correlated with rainfall in the $3 \mathrm{rd}$ and 4 th months previous to the trapping. In this case, the correlation was maximized in the 3 rd month $(r s=0.66, P<0.01)$. In(3L)P showed a positive and significant correlation with the mean temperature of the month previous to the trapping ( $r s=0.38, P<0.05$ ), and was negatively correlated the rainfall in the previous 2 months, especially in the first one $(r s=-0.52, P<0.01)$. The remaining 2 inversions showed a significant correlation with the mean temperature of 2 months: $\operatorname{In}(3 \mathrm{R}) \mathrm{P}$ with the 2 nd previous month $(r s=0.49, P<0.05)$ and In(3R)C with that of the trapping month $(r s=0.40, P<0.05)$. In(3R)P also showed significant correlations with rainfall of the 6 th $(r s=-0.41, P<0.05)$ and 7 th $(r s=-0.41, P<0.05)$ previous months.

Because of the great number of tests performed, these correlation coefficients must be interpreted with care (especially the $p>0.01$ significant ones). So, only $\operatorname{In}(2 \mathrm{~L}) \mathrm{t}$ and $\operatorname{In}(3 \mathrm{~L}) \mathrm{P}$ are reliable enough to be considered. But we cannot presume a causal effect of temperature and rainfall on the cyclic pattern of inversion frequencies as there are many other environmental variables which follow a cyclic pattern and could be correlated as well.

Conversely, a causal effect cannot be ruled out. The fact that the frequency of $\operatorname{In}(2 \mathrm{~L}) \mathrm{t}$ had a maximal correlation with the temperature and rainfall of the 3rd previous month could be the result of climatic selection acting on the whole population, and that would not reach equilibrium instantaneously. Notably, there was a very interesting fact supporting the climatic cause in frequency changes that may be mentioned: the 1981-82 winter mean temperature was remarkably warm (near $10^{\circ} \mathrm{C}$ ) (Fig 1). In 1982, In(3L)P reached its highest frequencies within those 4 years; that year, jointly with 1984 , In(2L)t reached its highest frequencies as well.

\section{DISCUSSION}

The geographic distribution of 4 cosmopolitan inversions of $D$ melanogaster (Mettler et al, 1977; Inoue and Watanabe, 1979; Stalker, 1980; Knibb et al, 1981; Inoue et al, 1984) suggests that common selective factors are operating. The existence of a latitudinal correlation in both hemisphere suggests that the selective factors are related to some climatic variable. In fact, Knibb (1982) found the correlation between inversion frequencies and maximum temperature to be generally positive. 
If temperature were the direct selective factor responsible for the latitudinal cline, a joint oscillation of the 4 inversion frequencies would be expected, with a maximum occurring in the warmest months. Our results, however, do not support this supposition. In fact, we have found several patterns: In $(2 \mathrm{~L}) \mathrm{t}$ and $\operatorname{In}(3 \mathrm{~L}) \mathrm{P}$ underwent cyclic frequency changes; In(2R)NS remained stable throughout the 4 years; $\operatorname{In}(3 \mathrm{R}) \mathrm{P}$ showed no cyclic oscillations, while $\operatorname{In}(3 \mathrm{R}) \mathrm{C}$ tended to increase its frequency with the years.

The cyclic behavior of $\operatorname{In}(2 \mathrm{~L}) \mathrm{t}$ and $\operatorname{In}(3 \mathrm{~L}) \mathrm{P}$ is strong evidence that they are submitted to seasonal selective factors. The increase in their frequencies in the hottest months agrees with geographic distribution correlated with temperature, and a direct selective effect of temperature is certainly a very tempting hypothesis. The cycle of frequencies of these inversions can be explained by heterogeneous environment over time, as follows: during the hot months the frequency increases due to the selective advantage of heterozygous individuals. There are 2 previous observations on $\operatorname{In}(2 \mathrm{~L}) \mathrm{t}$ that are in accordance with this. First, there is a higher productivity of In $(2 \mathrm{~L}) \mathrm{t}$ heterokaryotypic females in population cages at high temperatures (Watanabe and Watanabe, 1973; they refer to $\operatorname{In}(2 \mathrm{~L}) \mathrm{t}$ as $\operatorname{In}(2 \mathrm{~L}) \mathrm{B}$ ). Second, there is a positive correlation between temperature and flying activity in those individuals carrying inversions especially on the left arm of chromosome II (Stalker, 1980). In the winter time, $D$ melanogaster populations survive as adult flies that can withstand, for nearly 200 days, temperatures close to $10^{\circ} \mathrm{C}$ (Lumme and Lakovaara, 1983; David et al, 1983). As Drosophila development is only possible between $12^{\circ} \mathrm{C}$ and $32^{\circ} \mathrm{C}$ (David et al, 1983), and considering that the mean temperatures from December to April hardly ever goes over $12^{\circ} \mathrm{C}$, there will be very few generations during the months of non-trapping. The fall of $\operatorname{In}(2 \mathrm{~L}) \mathrm{t}$ and $\mathrm{In}(3 \mathrm{~L}) \mathrm{P}$ frequencies would probably be a consequence of a weaker resistance to cold or to a shorter life-span of the carriers of these inversions.

In any case, the cyclic fluctuations reported in this work cannot be generalized. Stalker (1980) reported a significant increase in the frequency of inversions from spring to fall, but only on the right arm of chromosomes II and III. Knibb (1986) found seasonal cyclic changes in the frequencies of $\operatorname{In}(2 \mathrm{R}) \mathrm{NS}$ and $\operatorname{In}(3 \mathrm{~L}) \mathrm{P}$ over the 2 years he studied. Despite the different results, those inversions that underwent year-by-year cycles reached a maximum frequency in the warmest months.

The overview of geographic distribution data points towards an origin due to macroclimatic factors associated with latitude, although, as pointed out by Knibb (1986), a free inversion effect in marginal populations could also be implicated (Lewontin, 1974). On the other hand, the different temporal variation patterns in different areas indicate that other factors are working. First, the ecological differences among localities will condition the adaptative response of the populations according to seasonal environmental changes (inversion could be implicated in this response). Inoue et al (1984) noted the importance of non-climatic environmental changes for latitudinal cline deviations. Second, the genetic differences for the same inversion among different places, resulting from selective or random processes, could certainly contribute to a differentiation of the response to environmental changes. Evidence of genetic differentiations in this sense was obtained by Voelker et al (1978), Knibb (1982) and Anderson et al (1987). They found that the latitudinal clines for allozymic loci located within or near the inversions $\operatorname{In}(2 \mathrm{~L}) \mathrm{t}$ and $\operatorname{In}(3 \mathrm{~L}) \mathrm{P}$ 
are not completely explained by the clines of those inversions. By including this factor, we are also in agreement with Fontdevilla et al, (1983), who suggested that the chromosome arrangement be considered as a set of supergenes which could respond in different ways, depending upon the environment.

\section{REFERENCES}

Anderson PR, Knibb WR, Oakeshott JG (1987) Observations on the extent and temporal stability of latitudinal clines for alcohol deshydrogenase allozymes and four chromosome inversions in Drosophila melanogaster. Genetica 75, 81-88

David JR, Clavel MF (1967) Influence de la température d'élevage sur la mortalité larvo-nymphale et la durée de développement de la Drosophile. Naturaliste Can 94, 209-219

David JR, Allemand R, Van Herrewege J, Cohet Y (1983) Ecophysiology: abiotic factors. In: The Genetics and Biology of Drosphila. (Ahsburner M, Carson HL, Thompson JN Jr, eds) Academic Press, London, Vol 3, 105-170

Dozhansky Th (1943) Genetics of natural populations. IX. Temporal changes in the composition of populations of Drosophila pseudoobscura. Genetics 28, 162-186

Fontdevilla A, Zapata C, Alvarez G, Sanchez L, Mendez J, Enriquez I (1983) Genetic coadaptation in chromosomal polymorphism of Drosophila subobscura. I. Seasonal changes of gametic disequilibrium in a natural population. Genetics 105, 935-955

Inoue Y, Watanabe TK, (1979) Inversion polymorphisms in Japanese natural populations of Drosophila melanogaster. Jpn J Genet 54, 69-82

Inoue Y, Watanabe T, Watanabe TK (1984) Evolutionary change of the chromosomal polymorphism in Drosophila melanogaster populations. Evolution 38, 753-765 Knibb WR (1982) Chromosome inversion polymorphisms in Drosophila melanogaster. II. Geographic clines and climatic associations in Australasia, North America and Asia. Genetica 58, 213-221

Knibb WR (1986) Temporal variation of Drosophila melanogaster Adh allele frequencies, inversion frequencies, and population sizes. Genetica 71, 175-190

Knibb WR, Oakeshott JG, Gibson JB (1981) Chromosome inversion polymorphisms in Drosophila melanogaster. I. Latitudinal clines and associations between inversions in Australasian populations. Genetics 98, 833-847

Levine L, Schwartz NM (1970) Laboratory Exercises in Genetics. CV Mosby, USA, p 83

Lewontin RC (1974) The Genetic Basis of Evolutionary Change. Columbia University Press, New York

Lumme J, Lakovaara S (1983) Seasonality and diapause in Drosophilids. In: The Genetics and Biology of Drosophila. (Ashburner M, Carson HL, Thompson JN Jr eds) Academic Press, London, Vol 3d, 171-220

McMillan I, Fitz-Earle M, Butler L, Robson DS (1970) Quantitative genetics of fertility. II. Lifetime egg production of Drosophila melanogaster - Experimental. Genetics 65, 355-369 
Mettler LE, Voelker RA, Mukai T, (1977) Inversion clines in populations of Drosophila melanogaster. Genetics 87, 169-176

Roca A, Sanchez-Refusta F, Graña C, Comendador MA (1982) Chromosomal polymorphism in a population of $D$ melanogaster. Drosophila Information Service $58,130-131$

Stalker HD (1980) Chromosome studies in wild populations of Drosophila melanogaster. II. Relationship of inversion frequencies to latitude, season, wing-loading and flight activity. Genetics 95, 211-223

Voelker RA, Cockerham CC, Johnson FM, Shaffer HE, Mukai T, Mettler LE (1978) Inversion fails to account for allozyme clines. Genetics 88G, 515-527

Watanabe TK, Watanabe T (1973) Fertility genes in natural populations of Drosophila melanogaster. III. Superiority of inversion heterozygotes. Evolution, 27, 468-475

Yule GU, Kendall MG (1950) An Introduction to the Theory of Statistics. Hafner, New York, 14th edn

Zacharopoulou A, Pelecanos M (1980) Seasonal and year-to-year inversion polymorphism in a southern Greek Drosophila melanogaster wild population. Genetica $54,105-111$ 